\title{
Assessment of hydrogeochemical characteristics of groundwater quality in the vicinity of Okpara coal and Obwetti fireclay mines, near Enugu town, Nigeria
}

\author{
Ahamefula U. Utom • Benard I. Odoh • \\ Boniface C.E. Egboka
}

Received: 5 September 2012/ Accepted: 6 January 2013/Published online: 7 February 2013

(C) The Author(s) 2013. This article is published with open access at Springerlink.com

\begin{abstract}
Hydrogeochemical assessments were carried out in the vicinity of Okpara coal and Obwetti fireclay mines, Enugu, Nigeria to investigate the hydrogeochemical characteristics and constituents of shallow groundwater. A total of 12 representative shallow groundwater samples were collected and analyzed for major cations and anions as well as trace metals like Fe and Mn. Distribution of major ions in these groundwater samples was calculated and the general trend among cations and anions was found to be $\mathrm{Ca} \rightarrow \mathrm{Na} \rightarrow \mathrm{Mg} \rightarrow \mathrm{K}$ and $\mathrm{SO}_{4} \rightarrow \mathrm{NO}_{3} \rightarrow \mathrm{Cl} \rightarrow$ $\mathrm{HCO}_{3}$, respectively. This means that water moving through the ground will react to varying degrees with the surrounding minerals (and other components), and it is these rock-water interactions that give the water its characteristic chemistry. Piper trilinear diagrams classified the hydrogeochemical facies into $\mathrm{Ca}-\mathrm{Mg}-\mathrm{Cl}, \mathrm{Ca}-\mathrm{Fe}-\mathrm{Mg}-\mathrm{SO}_{4}$ and $\mathrm{Ca}-\mathrm{Mg}-\mathrm{Na}-\mathrm{K}-\mathrm{Cl}-\mathrm{SO}_{4}$ water types. Ratios of $\mathrm{Cl}$ to $\mathrm{Na}, \mathrm{K}$ and $\mathrm{Mg}$ generally increased compared to those of $\mathrm{Cl}$ to $\mathrm{Ca}$ and $\mathrm{SO}_{4}$ which decreased indicating ion adsorption/ exchange processes due to the dissolution of drainage materials. The aquiferous units mainly in the northwestern region of the study area yield water of better quality than those toward the southeastern region.
\end{abstract}

Keywords Hydrogeochemistry - Water samples · Water types · Groundwater quality

A. U. Utom $(\bowtie) \cdot$ B. I. Odoh · B. C.E. Egboka

Department of Geological Sciences, Nnamdi Azikiwe

University, P.M.B. 5025 Awka, Nigeria

e-mail: greatgraham2@yahoo.com

\section{Introduction}

Purpose

About $80 \%$ of the earth's surface is covered by water yet qualitatively $97 \%$ of this vast natural resource falls unfit for human use (Rai 2004). Fresh water for life is $0.6 \%$ of the total water budget with the bulk of it tied up in groundwater (Gleeson et al. 2012). Groundwater has strategically remained valuable as the major and preferred source of drinking water because of its naturally high quality and availability in the face of surface water reservoir maintenance culture deficiency and regular supply inconsistencies. Water scarcity resulting from increasing demand for water over the years in different parts of the world has also been aggravated by the problems of water pollution or contamination. Majority of these problems results from improper management of water resources and environmental degradation from natural sources (Olowokudejo 2007).

Enugu town with a population of about 750,000 is one of the fastest growing cities of Nigeria. Intermittent water supply shortages are major problems of the inhabitants of the Enugu area, Nigeria (Utom et al. 2012). The dense population, the industries and the various other utilities place great demands on the scarce water supplied from both surface water and groundwater resources. In addition, the supply of water throughout the Enugu coal area is bedeviled by the acid mine drainage pollution from underground coal mine and scattered coal mine spoils on the surface (Egboka 1985; Nganje et al. 2011). Okpara coal mine, one of the five defunct and district mines (Onyeama, Obwetti, Okpara, Iva Valley and Ribadu) in the Enugu area, was opened in 1952 by the Nigerian Coal Corporation (Awoniyi 1977; Akande et al. 1992). Production in the 
mine declined from a peak of 3,040 tons in 1934 to 1,016 tons in 1990 and was closed down (Diala 1984) due to economic reasons (Nganje et al. 2010). Coal mining in the area has been noted to have caused significant degradation in groundwater quality and environment through the exposure of overburden and mine spoils to oxidations (Egboka 1985; Ezeigbo and Ezeanyim 1993).

With respect to the geologic and environmental understanding of the site (Utom et al. 2012), emphasis is given to those selected constituents that may have adverse physiological effects on groundwater quality and also previously reported in literature as undesirable for domestic purposes, i.e., $\mathrm{Fe}, \mathrm{Mn}, \mathrm{SO}_{4}, \mathrm{NO}_{3}$ (Okagbue and Onuoha 1986; Egboka 1985; Uma 1992; Adaikpoh et al. 2005). During this study, some physicochemical properties from shallow groundwaters in the area were determined and evaluated.

The main objective of this study is to assess and define the groundwater quality distribution and magnitude of potential contamination in the area. In addition to statistically documenting the present condition of shallow groundwater for future comparisons, the study should also be valuable to authorities responsible for groundwater exploitation and management.

Climate, vegetation, terrain geology and hydrogeology

The study area is located between latitudes $06^{\circ} 22^{\prime} \mathrm{N}$ and $06^{\circ} 27^{\prime} \mathrm{N}$ and longitudes $007^{\circ} 25^{\prime} \mathrm{E}$ and $007^{\circ} 30^{\prime} \mathrm{E}$. The study site areal extent is approximately $84 \mathrm{~km}^{2}$ and is situated at about $5 \mathrm{~km}$ west of Enugu city, southeastern Nigeria. It is closer to the neighboring town of Ngwo (about $4.7 \mathrm{~km}$ ) and also borders some parts of the Obwetti fireclay mine and coal processing plant. The Enugu's climate is humid and humidity is high during rains. The Sahara air mass, north-easterly dry winds causes the dry season (OctoberMarch) as it advances southwards while the Atlantic Ocean air mass causes the rainy season (March-October) as it moves northwards (Sanni 2007). Guinea (tropical) Savannah forms the vegetation belt of the Enugu area. Water resources availability is also limited due to the spatio-temporal variation of precipitation. At present, it is a general practice that nearly very single house built outside the municipal area drill a groundwater well for its own domestic use. The wells are generally drilled by local and small-scale contractors where scientific data gathered are of secondary importance. The study area has three predominant and conformable geologic formations (Fig. 1): the Enugu Shale (Campanian, consisting of mudstone, gray to dark gray shale and sandstone intercalation), the coaliferous Mamu Formation (Lower Maestrichtian, consisting of shale, mudstone and sandy shale with coal seam), and the heavily aquiferous Ajali Sandstone (Upper Maestrichtian, about $406 \mathrm{~m}$ thick and constituting of thick friable, poorly sorted, highly cross-bedded) that is generally whitish in color but sometimes iron-stained and occasionally intercalated with mudstone and shale. Stratigraphically, the Enugu Shale which overlies the Cross River Plain east of the escarpment is overlain by the Mamu Formation which in turn is overlain by the Ajali Sandstone. In the study area, the major streams or rivers, some of which appear fracturecontrolled in their flow paths give rise to part Trellis to part dendritic drainage pattern. Hydrology and hydrogeology of the area is controlled by topographic features. Two main aquifer systems one unconfined (Ajali Sandstone) and the other confined (Mamu Formation) exist. At high elevations, the highly permeable (Simpson 1954) and sometimes fractured (Reyment 1965) Ajali Sandstone which overlies the recharge area forms water table aquifers while the
Fig. 1 Geologic and physiographic maps of the study area

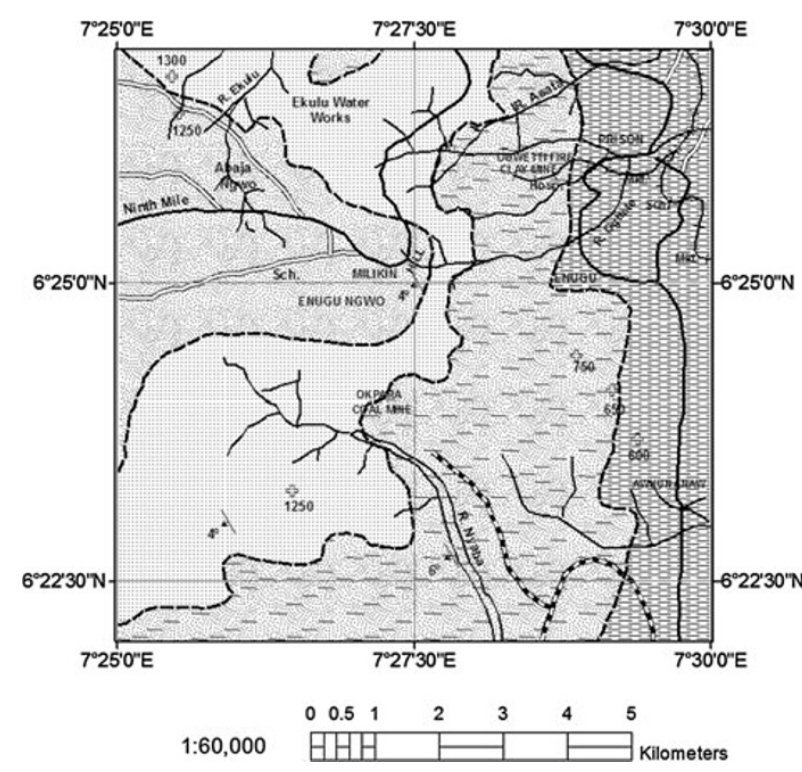

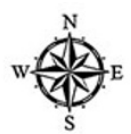

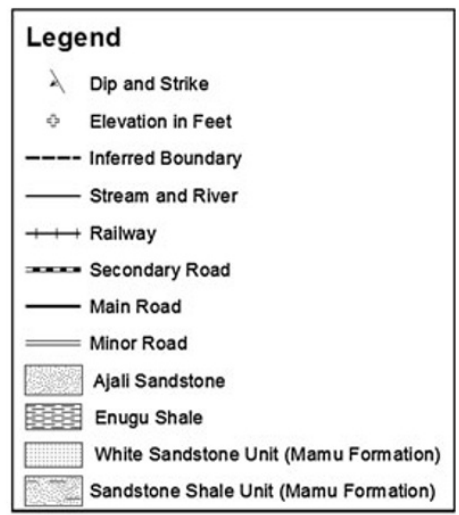


Mamu aquifers of the Mamu Formation occur deeper but are exposed where Ajali Sandstone has been lost due to erosion. The heavily gullied sandstone is overlain by lateritic/red earth deposits (Reyment 1965). Hydraulic parameters of aquifer as estimated through pumping test analysis by Egboka (1985), confirmed using geoelectric sounding by Utom (2012) and Odoh et al. (2012), showed that the transmissivity values in the area range between $4.4 \times 10^{4}$ and $3.2 \times 10^{5} \mathrm{~m}^{2}$ year $^{-1}$ while the hydraulic conductivity and groundwater velocity range between $9.2 \times 10^{-3}$ and $2.6 \times 10^{-2} \mathrm{cms}^{-1}$ and between 48.4 and 134.6 million year ${ }^{-1}$, respectively. The range of values of the hydraulic parameters indicates that the aquifer is characteristic of silty and clean sand aquifer materials (Domenico and Schwartz 1990).

\section{Hydrogeochemical analysis of collected groundwater samples}

Water sampling and physico-chemical analysis

Water sampling was carried out in the dry season (in August 2012) from different hand-dug wells (depth less than $30 \mathrm{~m}$ ) and water boreholes as well as contact spring running on coal mine spoils. Specific locations of studied wells, boreholes and contact spring were taken with the help of GARMIN GPSmap76CSx. The water samples were collected into $1 \mathrm{~L}$ polyethylene bottles which were precleaned with concentrated hydrochloric acid and distilled water. $\mathrm{pH}$ and temperature of the water samples were measured on-site with a Thermo electron Corporation Orion 3 Star $\mathrm{pH}$ Benchtop. This was also done to avoid unpredictable changes in characteristics as per the standard procedure (APHA 1995). Sampling protocols according to Classen (1982) and Barcelona et al. (1985) were adopted. Total dissolved solids (TDS), electrical conductivity (EC) or specific conductance and resistivity of collected water samples were measured using Delta Ohm HD 2306.0 conductivity meter. Water samples were collected with well purging because wells had not been recently drilled and purged. All the water samples were preserved in a refrigerator to exclude microbial activity and unwanted chemical reaction until analysis was completed within 2 days. The determinations of the other physico-chemical properties of the water samples were performed within 2 days of sampling.

HACH DR 2800 Spectrophotometer was used in the determination of different hydrogeochemical properties such as $\mathrm{Ca}, \mathrm{Mg}, \mathrm{Na}, \mathrm{K}, \mathrm{HCO}_{3}, \mathrm{Cl}, \mathrm{NO}_{3}, \mathrm{SO}_{4}, \mathrm{Fe}$ and $\mathrm{Mn}$. Analytical water test tablets prescribed for $\mathrm{HACH} \mathrm{DR}^{\circledR}$ Spectrophotometer 2800 using procedures outlined in the HACH DR 2800 Spectrophotometer manual were used for the examination of the water quality. Other analyses such as the determination of total hardness, $\mathrm{Mg}$ and $\mathrm{Ca}$ concentrations were done by complexometric titration method.

\section{Hydrogeochemistry}

Hydrogeochemical parameters of the collected groundwater samples were performed by Utom (2012). Water samples (Fig. 2) were collected mainly from a contact
Fig. 2 Base map of the study area showing various water sample locations

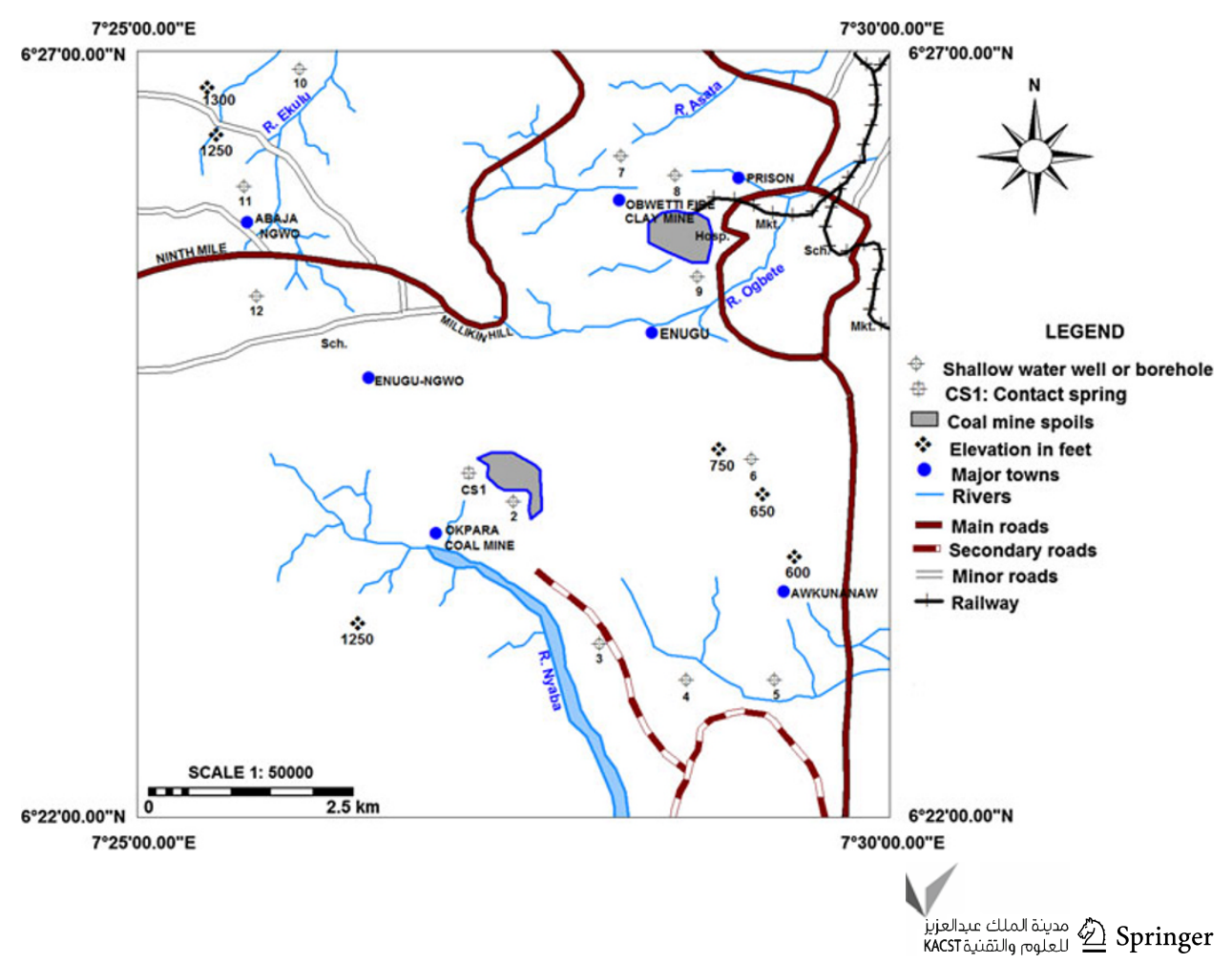


spring running over coal mine spoils (CS-1), shallow water wells (S-2, S-3, S-4, S-5, S-6, S-7, S-8 and S-9) and boreholes (S-10, S-11 and S-12). The analytical data quality was evaluated by computing the ionic balance, which is calculated by comparing the sum of the equivalents of the cations with the sum of the equivalents of the anions (Hounslow 1995). A positive result means that both an excess cations or insufficient anion exists, and a negative result means the opposite. For freshwater, ionic balance is assumed to be good if it is within the range of $\pm 10 \%$ (Celesceri et al. 1998). In this study, ionic balance values ranged from -0.91 to $+0.47 \%$.

Table 1 displays the result of the hydrogeochemical analysis of shallow groundwater samples, and Table 2 is the descriptive statistics of the analyzed samples along with the Nigerian Industrial Standards (Ofili 2007). Such drinking water standards are generally based on two main criteria (Davis and DeWiest 1966): (1) presence of objectionable taste, odor, and color and; (2) presence of substances with adverse physiological (health-effect) characteristics.

We evaluated the distribution of major ions in these groundwater samples and found the general trend among cations and anions to be $\mathrm{Ca} \rightarrow \mathrm{Na} \rightarrow \mathrm{Mg} \rightarrow \mathrm{K}$ and $\mathrm{SO}_{4} \rightarrow \mathrm{NO}_{3} \rightarrow \mathrm{Cl} \rightarrow \mathrm{HCO}_{3}$, respectively. The dispersion of ions in the groundwater of this terrain indicates nearly similar geochemical environment and climatic conditions (Reza and Singh 2009). This means that water moving through the ground will react to varying degrees with the surrounding minerals (and other components), and it is these rock-water interaction that give the water its characteristic chemistry. Amadi et al. (1987) and Odoh et al. (2012) noted that regional geology plays a very significant role in determining the hydrogeochemistry of groundwater system. Also, the mineralogy of the geological regime controls, to a large extent, the chemical quality of water permeating through the system (Singh 1987). The statistical regression analysis between TDS-EC, TDS-Mg, TDS$\mathrm{Ca}, \mathrm{TDS}-\mathrm{SO}_{4}$ showed very strong positive relations, with $R^{2}$ values of $0.992,0.985,0.979$ and 0.997 , respectively, and weak positive correlations $\left(R^{2}=0.319\right.$ and 0.433$)$ between TDS-Na and TDS-K, respectively, suggesting that the aquifer chemistry is controlled by these parameters (Odoh et al. 2012). The Pearson correlation matrix showing these relationships is provided in Table 3. Figure 3 also shows the linear relationship and strong coefficient of determination $\left(R^{2}=0.992\right)$ between TDS $(\mathrm{mg} / \mathrm{L})$ and EC $(\mu \mathrm{S} / \mathrm{cm})$. The calculated slope of 0.682 from this relationship compares favorably well with the generally acceptable approximate relationship: TDS $(\mathrm{mg} / \mathrm{L}) \approx 0.556-0.833 \mathrm{EC}$ $(\mu \mathrm{S} / \mathrm{cm})$ (Hem 1985). The relationship between iron concentration in $\mathrm{mg} / \mathrm{L}$ and $\mathrm{pH}$ is also $\operatorname{good}\left(R^{2}=-0.585\right)$.

As it is true for virtually all forms of contamination, the threshold values of pollution from coal mining activities are those whose concentrations are capable of causing harmful effects on previously unaffected water uses (Utom et al. 2012). Identification of contaminated waters in the field assists in the rationalization of sampling and designing of monitoring programs. Based on this, hydrogeochemistry in this paper is discussed in terms of:

1. Important physico-chemical attributes (such as $\mathrm{pH}, \mathrm{Fe}$, $\mathrm{Mn}$, Total Hardness, $\mathrm{SO}_{4}$ and EC) of water quality affected by coal mining operations taking cognizance of the overall geology and environmental situations;

2. Changes in the absolute concentrations of the major cations and anions whether or not affected by mining activity. This basic information is encapsulated in detailed explanation of the ionic and hydrogeochemical compositions while discriminating the distinct water types in the area. Comparisons are also made with background values inferred not to be affected by mining activities.

Changes in water chemistry in the Okpara coal and Obwetti fireclay mines

Water samples S-10, S-11, and S-12 were assumed to represent the background water chemistry had mining not taken place. The basis for this assumption stems from the water samples' strategic location away from the mining site and the contrasting recorded values of the physico-chemical attributes of water quality affected by coal mining operations. These background values show that the molar concentration of calcium and magnesium is nearly equal to that of bicarbonate, indicating that the dominant sources of these three ions are calcitic local rocks. Although sulfate concentration is low, the molar concentration of calcium plus magnesium to sulfate, both at background sites and at sites affected by mining show a progress rate of increase with each other similar to that for the dissolution of gypsum (Hackbarth 2010). Samples S-3, and S-5 also show somewhat similar background water chemistry, even though they are closer to the mine spoil sites of Okpara coal mine. The best explanation to this is the strategic location of the shallow water wells along the Nyaba river, which tell much about the sites hydrogeology and attenuation capacity of the highly porous investigated alluvial media.

Increase in sulfate ion concentration is caused by increase in rates of oxidation of sulfide minerals in the coal mine spoil as defined by the relationship between acidity and sulfate governed by the following chemical reactions involving pyrite (Caruccio 1968; Stumm and Morgan 1996):

$\mathrm{Fe}_{2}+\mathrm{H}_{2} \mathrm{O}+3^{1} / 2 \mathrm{O}_{2} \rightleftharpoons \mathrm{FeSO}_{4}+\mathrm{H}_{2} \mathrm{SO}_{4}$

Ferrous sulfate thus formed from the oxidation of pyrite, may be oxidized further to ferric sulfate in presence of 


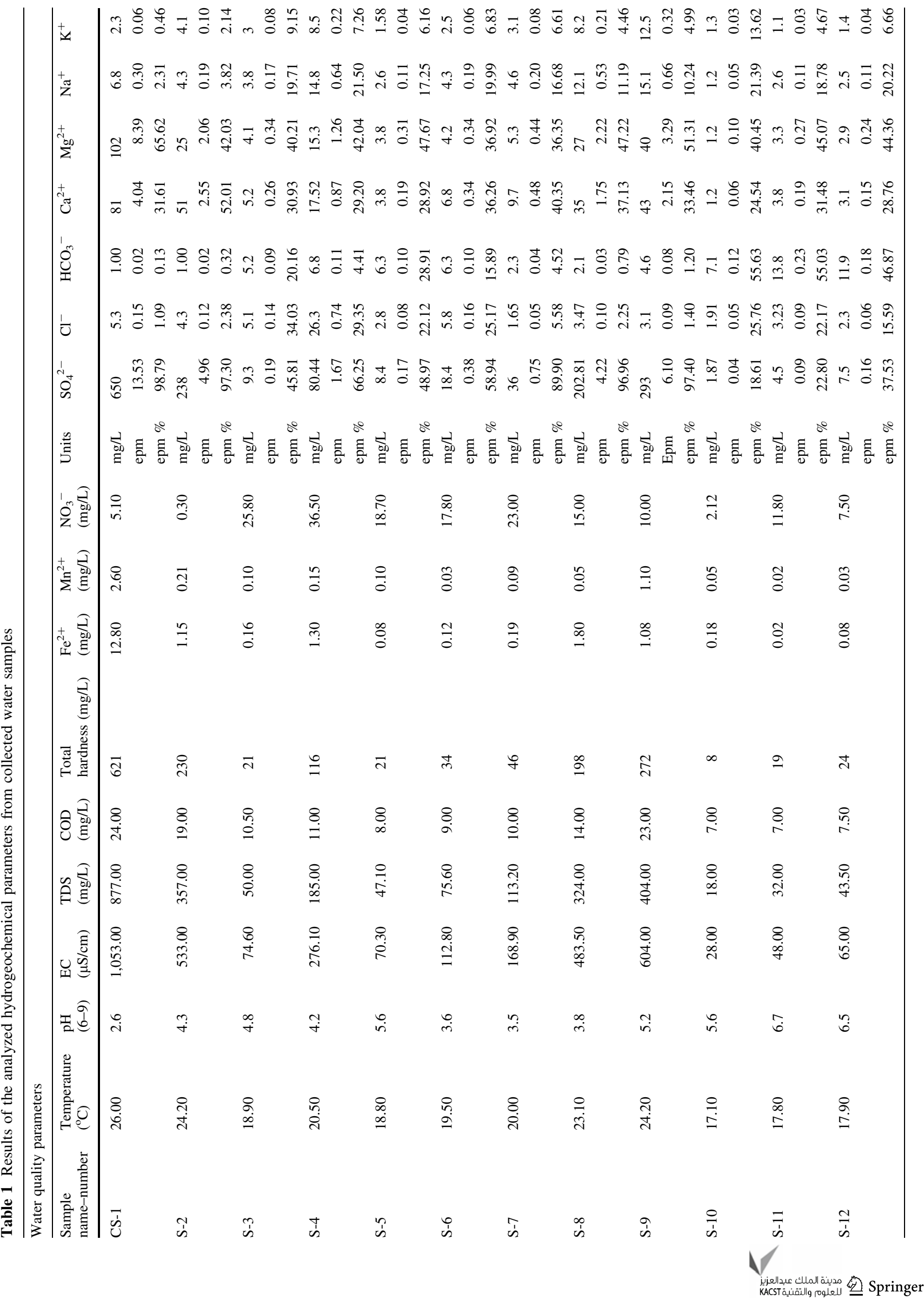


Table 2 Descriptive statistics of the analyzed hydrogeochemical properties compared with the Nigerian Industrial Standards

\begin{tabular}{|c|c|c|c|c|c|c|c|}
\hline \multirow[t]{2}{*}{ Parameters } & \multirow{2}{*}{$\begin{array}{l}\text { No. of } \\
\text { Samples }\end{array}$} & \multirow[t]{2}{*}{ Min } & \multirow[t]{2}{*}{ Max } & \multirow[t]{2}{*}{ Mean } & \multirow[t]{2}{*}{ STDEV. } & \multicolumn{2}{|c|}{ Nigerian Industrial Standard } \\
\hline & & & & & & $\begin{array}{l}\text { Maximum } \\
\text { permissible limit }\end{array}$ & Health impact \\
\hline Temperature $\left({ }^{\circ} \mathrm{C}\right)$ & 12 & 17.1 & 26 & 20.7 & 3.0 & Ambient & None \\
\hline $\mathrm{pH}$ & 12 & 2.6 & 6.7 & 4.7 & 1.3 & $6.5-8.5$ & None \\
\hline $\mathrm{EC}(\mu \mathrm{S} / \mathrm{cm})$ & 12 & 28 & 1,053 & 293.1 & 315.6 & 1,000 & None \\
\hline Resistivity ( $\Omega \mathrm{m}$ ) & 12 & 9.5 & 357 & 114 & 102.5 & N/A & N/A \\
\hline TDS (mg/L) & 12 & 18 & 877 & 210.5 & 251.1 & 500 & None \\
\hline Total Hardness (mg/L) & 12 & 8 & 621 & 134.2 & 179.5 & 500 & None \\
\hline $\mathrm{Fe}^{2+}(\mathrm{mg} / \mathrm{L})$ & 12 & 0.02 & 12.8 & 1.6 & 3.6 & 0.3 & None \\
\hline $\mathrm{Mn}^{2+}(\mathrm{mg} / \mathrm{L})$ & 12 & 0.02 & 2.6 & 0.4 & 0.8 & 0.2 & Neurological disorder \\
\hline $\mathrm{SO}_{4}{ }^{2-}(\mathrm{mg} / \mathrm{L})$ & 12 & 1.87 & 650 & 129.2 & 194.0 & 100 & None \\
\hline $\mathrm{Cl}^{-}(\mathrm{mg} / \mathrm{L})$ & 12 & 1.65 & 26.3 & 5.4 & 6.7 & 250 & None \\
\hline $\mathrm{NO}_{3}{ }^{-}(\mathrm{mg} / \mathrm{L})$ & 12 & 0.3 & 36.5 & 14.5 & 10.6 & 50 & $\begin{array}{l}\text { Cyanosis, and asphyxia ('blue-baby syndrome') } \\
\text { in infants under } 3 \text { months }\end{array}$ \\
\hline $\mathrm{HCO}_{3}^{-}(\mathrm{mg} / \mathrm{L})$ & 12 & 1 & 13.8 & 5.6 & 4.1 & N/A & N/A \\
\hline $\mathrm{Ca}^{2+}(\mathrm{mg} / \mathrm{L})$ & 12 & 1.2 & 81 & 21.8 & 25.3 & N/A & N/A \\
\hline $\mathrm{Mg}^{2+}(\mathrm{mg} / \mathrm{L})$ & 12 & 1.2 & 102 & 19.5 & 28.8 & 0.2 & Consumer acceptability \\
\hline $\mathrm{Na}^{+}(\mathrm{mg} / \mathrm{L})$ & 12 & 1.2 & 15.1 & 6.2 & 4.9 & 200 & None \\
\hline $\mathrm{K}^{+}(\mathrm{mg} / \mathrm{L})$ & 12 & 1.1 & 12.5 & 4.1 & 3.6 & N/A & N/A \\
\hline COD & 12 & 7 & 24 & 12.5 & 6.2 & N/A & N/A \\
\hline
\end{tabular}

Table 3 Pearson correlation matrix for the various hydrogeochemical properties of the groundwater samples

\begin{tabular}{|c|c|c|c|c|c|c|c|c|c|c|c|c|c|c|c|c|c|}
\hline $\begin{array}{l}\text { Water } \\
\text { quality } \\
\text { parameters }\end{array}$ & $\begin{array}{l}\text { Temperature } \\
\left({ }^{\circ} \mathrm{C}\right)\end{array}$ & $\mathrm{pH}$ & $\begin{array}{l}\mathrm{EC} \\
(\mu \mathrm{S} / \\
\mathrm{cm})\end{array}$ & $\begin{array}{l}\text { Resistivity } \\
(\Omega \mathrm{m})\end{array}$ & $\begin{array}{l}\text { TDS } \\
(\mathrm{mg} / \mathrm{L})\end{array}$ & $\begin{array}{l}\text { Total } \\
\text { hardness } \\
(\mathrm{mg} / \mathrm{L})\end{array}$ & $\mathrm{Fe}$ & Mn & $\mathrm{SO}_{4}$ & $\mathrm{Cl}$ & $\mathrm{NO}_{3}$ & $\mathrm{HCO}_{3}$ & $\mathrm{Ca}$ & $\mathrm{Mg}$ & $\mathrm{Na}$ & $\mathrm{K}$ & COD \\
\hline Temp. $\left({ }^{\circ} \mathrm{C}\right)$ & 1 & & & & & & & & & & & & & & & & \\
\hline $\mathrm{pH}$ & -0.651 & 1 & & & & & & & & & & & & & & & \\
\hline $\mathrm{EC}(\mu \mathrm{S} / \mathrm{cm})$ & 0.957 & -0.621 & 1 & & & & & & & & & & & & & & \\
\hline $\begin{array}{l}\text { Resistivity } \\
\qquad(\Omega \mathrm{m})\end{array}$ & -0.809 & 0.652 & -0.683 & 1 & & & & & & & & & & & & & \\
\hline $\begin{array}{l}\text { TDS } \\
\qquad(\mathrm{mg} / \mathrm{L})\end{array}$ & 0.918 & -0.627 & 0.992 & -0.632 & 1 & & & & & & & & & & & & \\
\hline $\begin{array}{l}\text { Total } \\
\text { hardness } \\
(\mathrm{mg} / \mathrm{L})\end{array}$ & 0.899 & -0.596 & 0.985 & -0.598 & 0.998 & 1 & & & & & & & & & & & \\
\hline $\mathrm{Fe}$ & 0.674 & -0.585 & 0.843 & -0.389 & 0.904 & 0.917 & 1 & & & & & & & & & & \\
\hline $\mathrm{Mn}$ & 0.720 & -0.477 & 0.867 & -0.410 & 0.912 & 0.927 & 0.930 & 1 & & & & & & & & & \\
\hline $\mathrm{SO}_{4}$ & 0.906 & -0.584 & 0.986 & -0.586 & 0.997 & 0.998 & 0.907 & 0.927 & 1 & & & & & & & & \\
\hline $\mathrm{Cl}$ & 0.064 & -0.222 & 0.061 & -0.284 & 0.051 & 0.051 & 0.061 & -0.019 & 0.003 & 1 & & & & & & & \\
\hline $\mathrm{NO}_{3}$ & -0.246 & -0.180 & -0.320 & -0.228 & -0.323 & -0.340 & -0.264 & -0.309 & -0.375 & 0.655 & 1 & & & & & & \\
\hline $\mathrm{HCO}_{3}$ & -0.771 & 0.847 & -0.695 & 0.621 & -0.670 & -0.635 & -0.507 & -0.477 & -0.643 & 0.027 & 0.073 & 1 & & & & & \\
\hline $\mathrm{Ca}$ & 0.960 & -0.599 & 0.990 & -0.666 & 0.979 & 0.973 & 0.820 & 0.833 & 0.975 & 0.031 & -0.385 & -0.705 & 1 & & & & \\
\hline $\mathrm{Mg}$ & 0.845 & -0.578 & 0.959 & -0.542 & 0.985 & 0.992 & 0.950 & 0.960 & 0.989 & 0.037 & -0.316 & -0.589 & 0.936 & 1 & & & \\
\hline $\mathrm{Na}$ & 0.581 & -0.344 & 0.505 & -0.656 & 0.433 & 0.412 & 0.174 & 0.271 & 0.390 & 0.554 & 0.363 & -0.319 & 0.455 & 0.375 & 1 & & \\
\hline K & 0.546 & -0.213 & 0.417 & -0.586 & 0.319 & 0.295 & -0.021 & 0.148 & 0.296 & 0.371 & 0.243 & -0.316 & 0.364 & 0.240 & 0.946 & 1 & \\
\hline COD & 0.958 & -0.522 & 0.944 & -0.895 & 0.911 & 0.902 & 0.674 & 0.798 & 0.912 & 0.000 & -0.329 & -0.689 & 0.944 & 0.861 & 0.542 & 0.545 & 1 \\
\hline
\end{tabular}




\section{Regression of TDS $(\mathrm{mg} / \mathrm{L})$ by EC $(\mu \mathrm{s} / \mathrm{cm})\left(R^{2}=0.983\right)$}

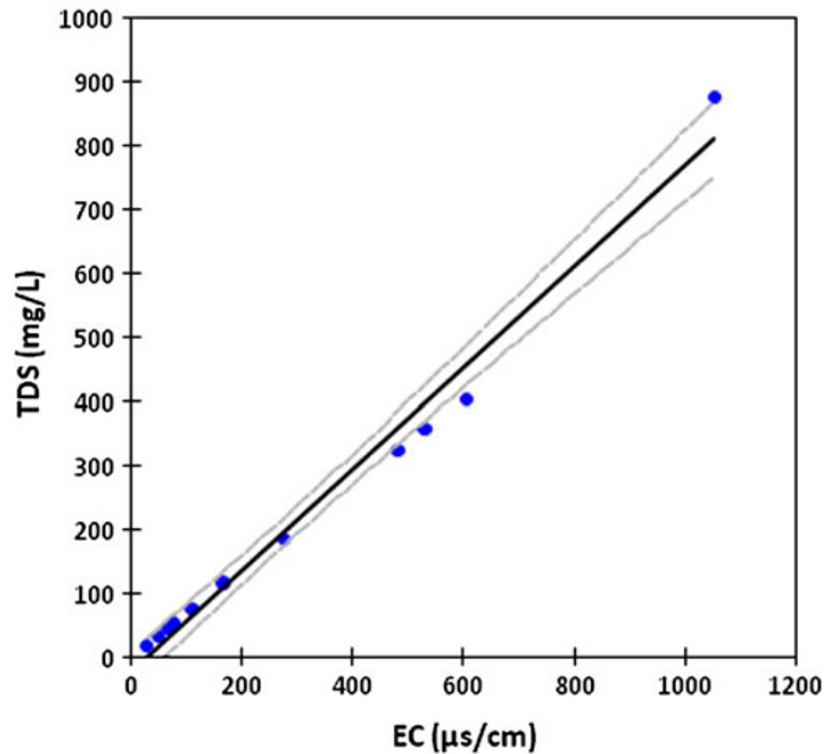

\section{Model}

Conf. interval (Mean 95\%)

Fig. 3 Correlation between total dissolved solids (TDS) and electrical conductivity (EC)

bacteria and dissolution in acidic water (Singh and Mridula 1985),

$\mathrm{Fe}_{2}\left(\mathrm{SO}_{4}\right)_{3} \rightleftharpoons 2 \mathrm{Fe}^{3+}+3 \mathrm{SO}_{4}^{2-}$

$\mathrm{Fe}^{3+}$ can hydrolyze on,

$\mathrm{Fe}^{3+}+3 \mathrm{H}_{2} \mathrm{O} \rightleftharpoons \mathrm{Fe}(\mathrm{OH})_{3}+3 \mathrm{H}^{+}$

to form acidity and iron hydroxide. The $\mathrm{Fe}^{3+}$ formed during acid-generating reactions further reacts with the available pyrite to form additional acidity, ferrous and sulfate ions. Although sulfate and iron arise from a common source, the acidity generated is a function of oxidation state of iron. However, sulfate remains constant and can be used to approximate the degree of acidity present or that was present before neutralization took place.

The hydrogen ion, produced during the oxidation of sulfide minerals (Eq. 1) and in the subsequent hydrolysis (Eq. 3) of the ferric ion, increases the weathering rate of the abundant carbonate minerals in the spoil according to the following reactions (Hem 1985):

$$
\begin{aligned}
& \mathrm{CaCO}_{3}+\mathrm{H}^{+} \rightleftharpoons \mathrm{Ca}^{2+}+\mathrm{HCO}_{3}^{-} \\
& \left.2 \mathrm{CaMg}^{2} \mathrm{CO}_{3}\right)+2 \mathrm{H}^{+} \rightleftharpoons 2 \mathrm{Ca}^{2+}+2 \mathrm{Mg}^{2+}+2 \mathrm{HCO}_{3}^{-}
\end{aligned}
$$

Since these minerals contribute most of the dissolved cations in the natural system, an increased rate of weathering does not change the relative abundance of calcium and magnesium, but increases their concentrations. Hence, Eq. (1) through (5) indicates that the production of

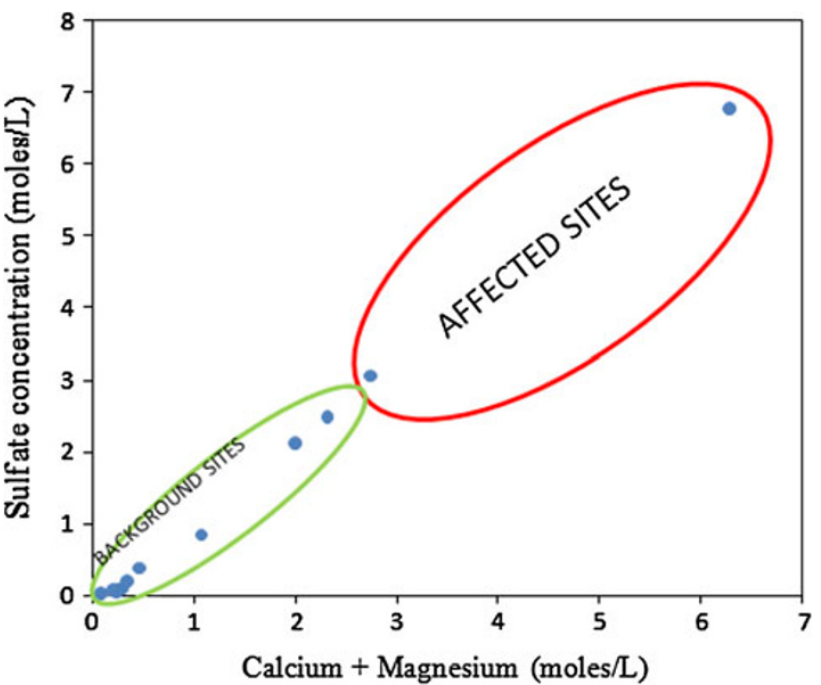

Fig. 4 Relationship of molar concentrations of calcium plus magnesium to sulfate

$1 \mathrm{~mol}$ of sulfate should produce $2 \mathrm{~mol}$ of calcium plus magnesium either from dolomite (Eq. 5), aragonite (Eq. 4) or calcite (Eq. 4) regardless of the amounts of calcium and magnesium. In this study, the relationship between the molar concentration of calcium plus magnesium to sulfate shows a linear trend (Fig. 4) with a slope of $0.98 \mathrm{~mol}$ of sulfate per $2 \mathrm{~mol}$ of calcium plus magnesium. This clearly illustrates the correctness of the sulfide mineral oxidation processes stated in the above equations.

$\mathrm{pH}$

The average value of $\mathrm{pH}$ in the analyzed water samples shows a slightly acidic value of 4.7. Among the samples, about $83 \%$ record values lower than the minimum (6.5) prescribed for water, whereas samples S-11 and S-12 exhibit values within the permissible limits. Low $\mathrm{pH}$ in the sampled waters of the study area, however, can be attributed to the influence of the acid mine drainage and possible acidic lateritic soil, forestry activity, acid precipitation, and fulvic and humic soils (Gray 1996; Raghunath et al. 2001).

Iron and manganese

Iron is of course a common component of mine drainage which can have a detrimental effect on aquatic life, water uses and man-made structures (Callaghan and Earle 1998). In this study, up to $42 \%$ of the analyzed $\mathrm{Fe}^{2+}$ content was beyond the Nigerian Industrial Standards. Manganese is another metal that is widely distributed in mine drainage. Manganese can be present in a variety of forms and compounds and complexes with organic compounds. In the study area, manganese concentration ranged from 0.03 to 
$2.6 \mathrm{mg} / \mathrm{L}$. Up to $25 \%$ of the analyzed manganese concentration was beyond the maximum permissible limit as shown in Table 2.

Total hardness

Hardness is measure of the occurrence and abundance of divalent cations, that is, $\mathrm{Ca}^{2+}, \mathrm{Mg}^{2+}$. Very high hardness values in potential acid mine water indicate that the waters differ from the more common type of hard waters, in that the sulfate with almost no bicarbonate is the dominant anion. According to Caruccio et al. (1977), the high hardness values $(621 \mathrm{mg} / \mathrm{L})$ coupled with the high acidity and low $\mathrm{pH}$ (2.6) values registered for sample CS-1 indicate that the primary cation contributing to it is soluble iron apart from $\mathrm{Ca}^{2+}$ and $\mathrm{Mg}^{2+}$ ions. Such waters can be classified as $\mathrm{Ca}-\mathrm{Fe}-\mathrm{Mg}$ sulfate type. In this study, Total

Table 4 Classification of groundwater samples based on Total hardness (Todd 1980)

\begin{tabular}{ll}
\hline Hardness $\left(\mathrm{mg} / \mathrm{L} \mathrm{CaCO}_{3}\right)$ & Water classification \\
\hline $0-75$ & Soft \\
$75-150$ & Moderately hard \\
$150-300$ & Hard \\
$>300$ & Very hard \\
\hline
\end{tabular}

hardness ranged from 8 to $621 \mathrm{mg} / \mathrm{L}$, and based on the classification guidelines in Table 4 , up to $58 \%$ of the analyzed water samples would be considered soft.

Sulfate and electrical conductivity

Electrical conductivity usually taken as a measure of the total dissolved salts in water is also sensitive to sulfate ions; this means that the two parameters are closely associated. Figures 5 and 6 show the spatial distribution of the sulfate content and EC in the study area. Generally, the groundwaters in the northwestern region are more potable in terms of the physico-chemical parameters than in the southeastern and northeastern region of the investigated area. Although details about the tectonic structures have not been defined in this study, it could be hypothesized that the complex nature of the fracture zones in the Enugu coal mine areas may be acting as a boundary between the same hydrolithological unit, and define the place where aquifer parameters varies. In the same vein we cannot rule out the fact the amount of groundwater contamination will depend on the hydrogeology of the area and attenuation capacity of the investigated medium (Utom 2012). According to Gray (1996), the advantage of using the two parameters to trace AMD is that unlike other ions, it is not removed to any great extent by sorption or precipitation processes, being unaffected by fluctuations in $\mathrm{pH}$.
Fig. 5 Sulfate concentration $(\mathrm{mg} / \mathrm{L})$ distribution in the study area

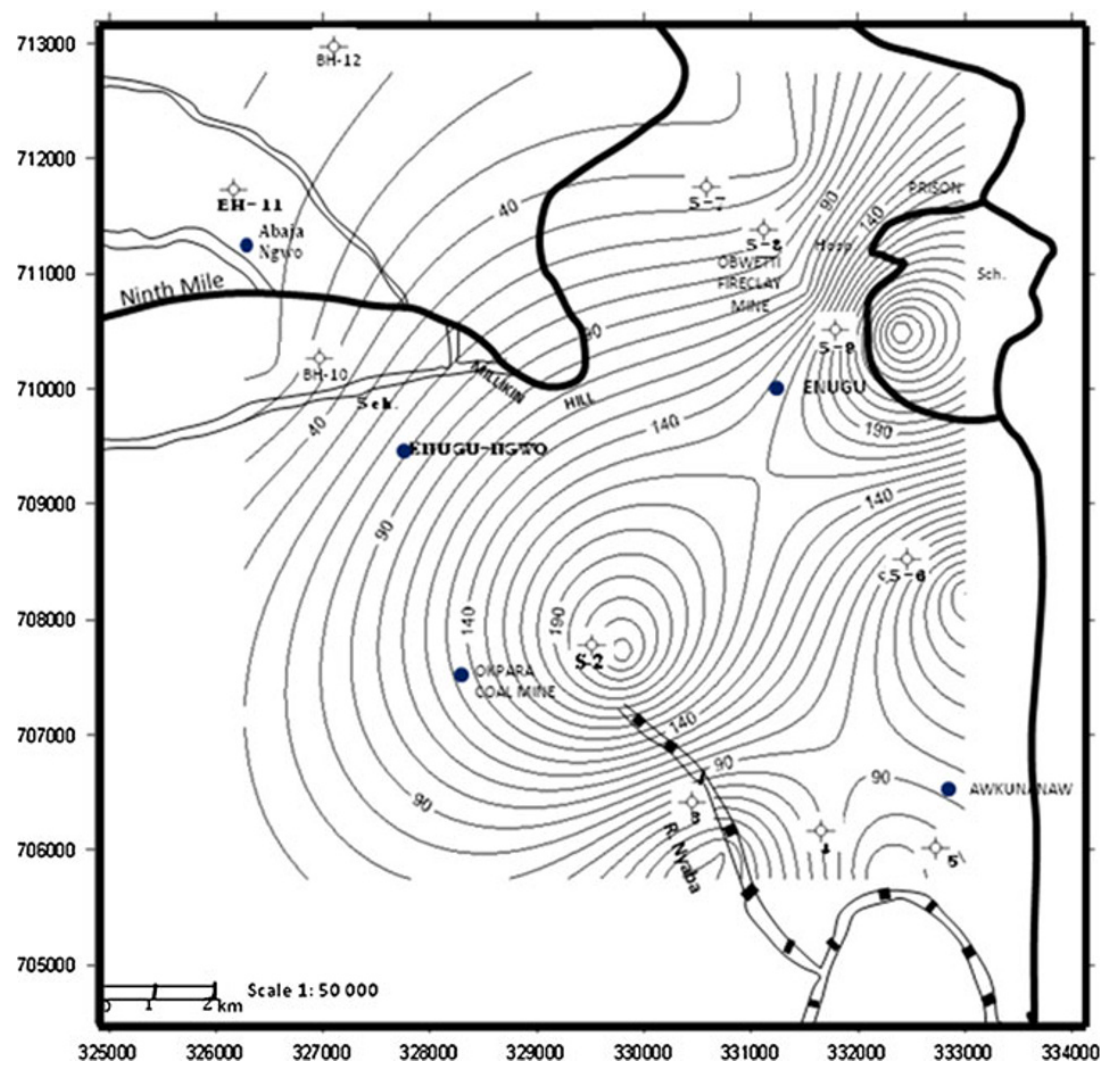


Fig. 6 Specific conductance of water $(\mu \mathrm{S} / \mathrm{cm})$ distribution in the study area

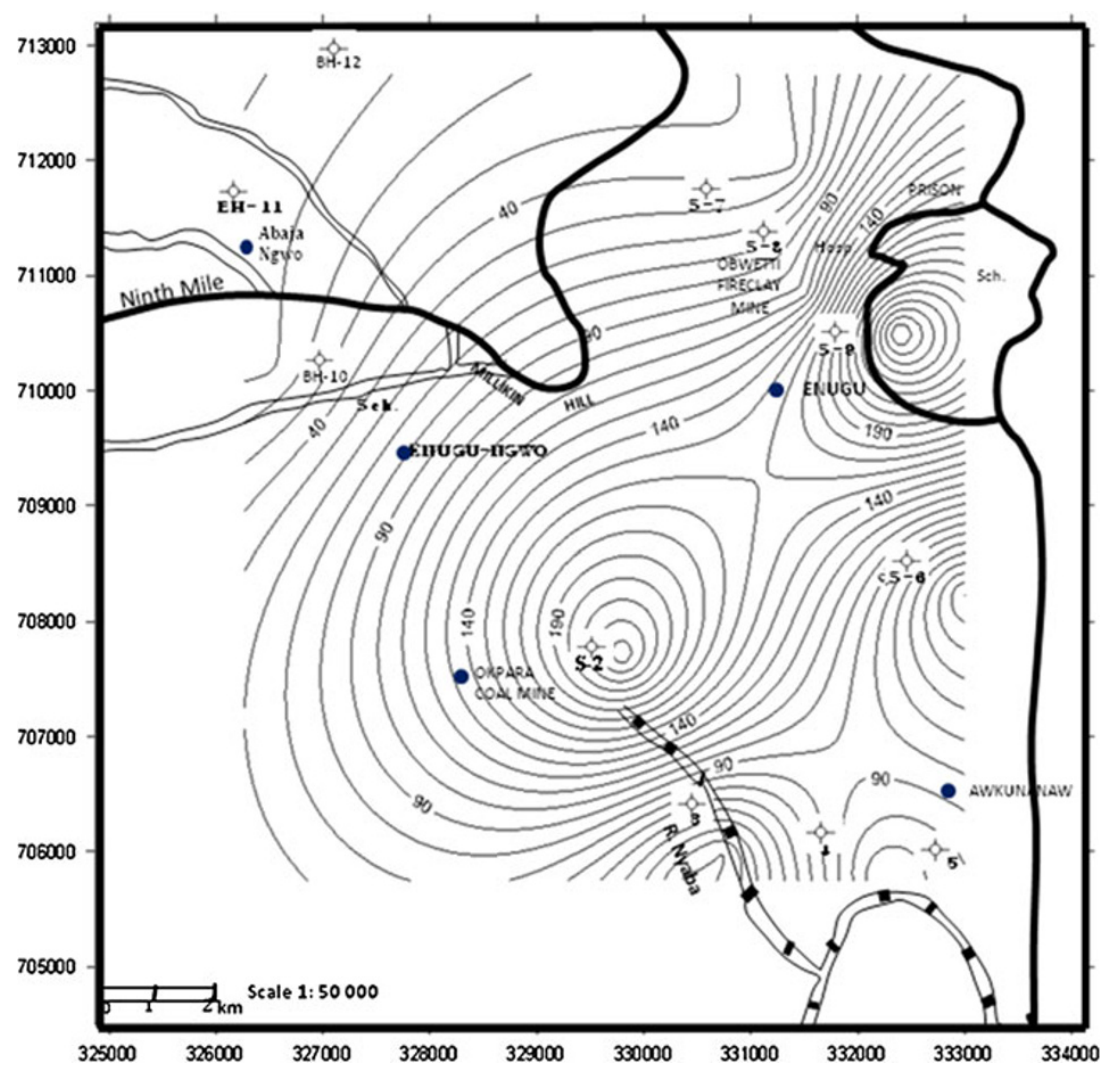

Table 5 Sulfate concentration of the analyzed groundwater samples in mole/L

\begin{tabular}{lllllllllllll}
\hline Sample codes & CS-1 & S-2 & S-3 & S-4 & S-5 & S-6 & S-7 & S-8 & S-9 & S-10 & S-11 & S-12 \\
\hline Sulfate concentration (mole/L) & 6.77 & 2.48 & 0.10 & 0.84 & 0.89 & 0.19 & 0.38 & 2.11 & 3.05 & 0.19 & 0.05 & 0.08
\end{tabular}

Sulfate concentration in the natural state is generally less than $0.5 \mathrm{~mol} / \mathrm{L}$ (water samples S-3, S-5, S-6, S-7, S-8, S-10, S-11, and S-12) (Table 5); but in this study, they can range as high as $3.5 \mathrm{~mol} / \mathrm{L}$ at sites influenced by mining activity. In the area of investigation, up to $33 \%$ of the analyzed water samples (CS-1, S-2, S-8 and S-9) were above the maximum permissible limit of the Nigerian Industrial Standards. The sulfate content spreads between 1.87 and $650 \mathrm{mg} / \mathrm{L}$ averaging $129.2 \mathrm{mg} / \mathrm{L}$.

King (1994) noted that the normal range of lake, river and groundwater conductivities is from 1 to $20 \mathrm{mS} / \mathrm{m}$. In this study, the specific conductance of up to $42 \%$ of the water samples (CS-1, S-2, S-4, S-8, and S-9) analyzed ranged from 28 to $105.3 \mathrm{mS} / \mathrm{m}$. It is also suggestive enough to state that the analyzed water samples in terms of quality have not been seriously degraded by the abandoned coal mining activities in the area. This supports the work of Uma (1992), who noted that the mine drainage has not seriously degraded the chemistry of the receiving streams as the $\mathrm{pH}$, $\mathrm{EC}$ and thus the dissolved ions were just increased less than $10 \%$ of the values in the unaffected regions.
Ionic composition and hydrogeochemical composition

To further evaluate and interpret the groundwater composition in the study area, major ions were expressed in units of milliequivalents per liter (meq/L) and plotted on Piper trilinear diagram (Fig. 7). The graphical treatment of the hydrogeochemical parameters allows for easy discrimination of distinct water types and/or characters by plotting in various subareas of the diamond. Details regarding the geochemical interpretation of water samples can be found in Piper (1953) and Hem (1985).

The study area has high $\mathrm{Cl}+\mathrm{SO}_{4}$ relative to $\mathrm{HCO}_{3}+\mathrm{CO}_{3}$ (see anion triangle in Fig. 7), which indicates a total deviation from a carbonate aquifer type (Daghrah 2009; Ghanem and Ghannam 2010). In the cation triangle, about $58 \%$ of the sample set (S-2, S-3, S-4, S-5, S-6, S-7, and S-8) was Ca-type, $33 \%$ of the sample set (S-10, S-11, S-12) showed no dominant type of cation and only sample CS-1 was of the Mg-type. Of the twelve samples, nine (CS-1, S-2, S-3, S-4, S-5, S-6, S-7, S-8 and S-9), represented $75 \%$ of the analyzed water samples, fall 
Fig. 7 Piper trilinear diagrams for studied groundwater samples

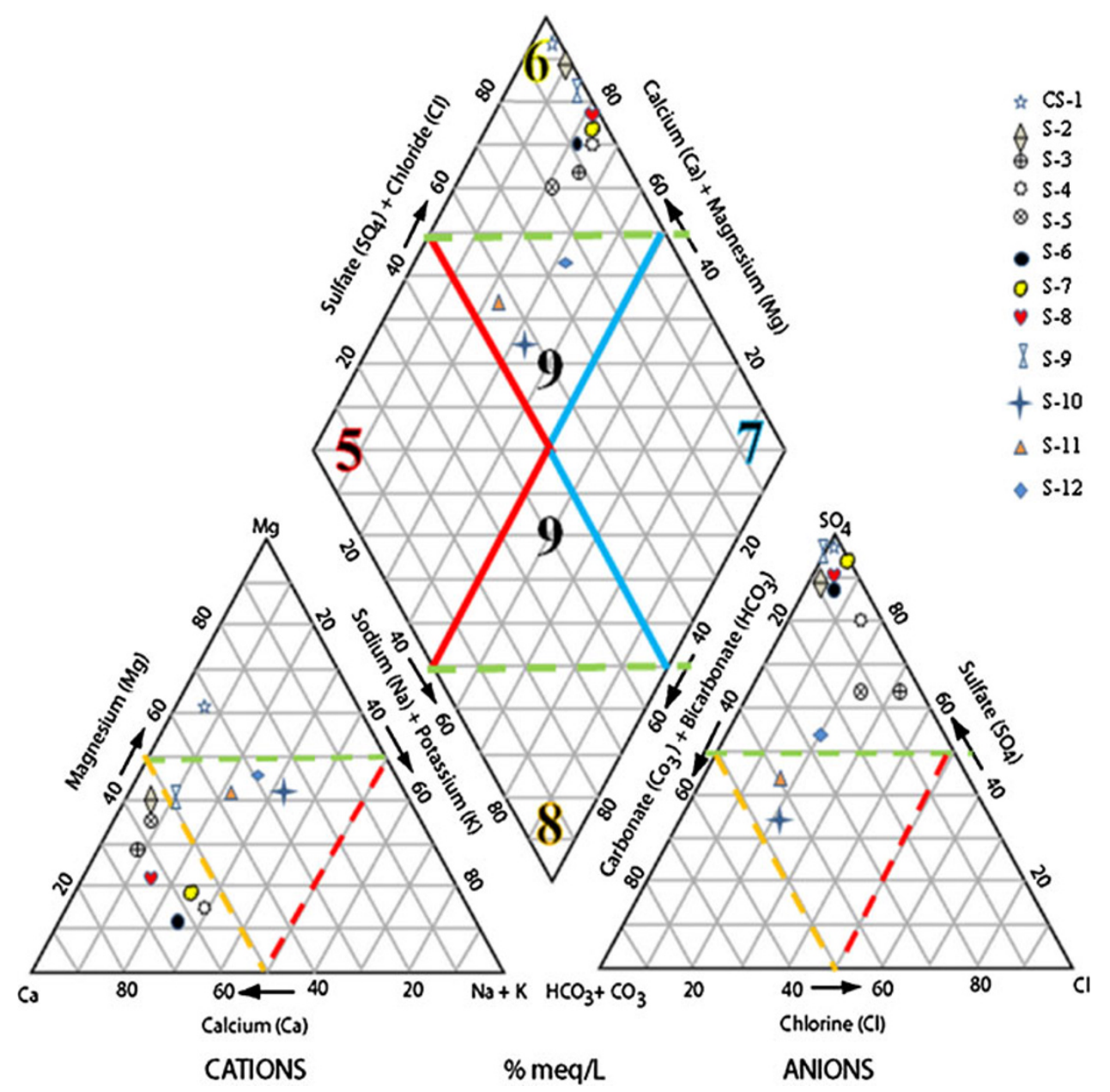

in area 6, indicating that the chemical properties of groundwater are dominated by alkaline earths $(\mathrm{Ca}, \mathrm{Mg})$ and strong acids $\left(\mathrm{SO}_{4}, \mathrm{Cl}\right)$. Three samples (S-10, S-11, S-12) fall in area 9, indicating no dominant cation-anion pair. None of the samples indicated the dominance of alkaline earths and weak acids (area 5), alkalis and strong acids (area 7) or alkalis and weak acids (area 8). In summary, most samples are characterized by the dominance of $\mathrm{Ca}$, $\mathrm{Mg}, \mathrm{SO}_{4}$ and $\mathrm{Cl}$ and the piper trilinear diagram indicates three water types (Deutsch 1997): $\mathrm{Ca}-\mathrm{Mg}-\mathrm{Cl}, \mathrm{Ca}-\mathrm{Fe}-\mathrm{Mg}-$ $\mathrm{SO}_{4}$ and $\mathrm{Ca}-\mathrm{Mg}-\mathrm{Na}-\mathrm{K}-\mathrm{Cl}-\mathrm{SO}_{4}$. This supports the work of Ezeigbo and Ezeanyim (1993) which shows that magnesium is the dominant cation and sulfate is the predominating anion.

Ionic exchange

It was also necessary to examine the rock-water interactions that give the water its characteristic chemistry with respect to the origin of the rock materials. Ion exchange is a type of adsorption/desorption phenomenon that applies principally to material with a porous lattice containing fixed charges (Deutsch 1997). According to Al-Ruwaih and Ben-Essa (2004), materials that have colloidal size particles, such as clay minerals, are the most common ion exchangers in the soil and aquifer environments. They have the capability to exchange ionic constituents adsorbed on particle surfaces. Electrostatic attraction of clay minerals brings dissolved cations to the clay surface to balance the charge. Low concentrations of calcium compared with sodium indicate the absence of readily soluble calcium minerals or the action of base exchange where calcium has been exchanged for sodium.

The ions that were analysed for, and whose concentrations are not very sensitive to, pyrite oxidation reactions include $\mathrm{Na}^{+}$and $\mathrm{Ca}{ }^{2+}$. In the area under study, the concentration of $\mathrm{Na}^{+}$increases while that of $\mathrm{Ca}^{2+}$ decreases in moving from notably the Ajali aquifer (S-10, S-11 and S-12) down to the Mamu aquifer. Overall, this trend can be accounted for by cation exchange reactions that occur as the water flows through the sand and shale units of the aquifer system. As infiltrating water encounters the Ajali sandstone unit, the water acquires small concentrations of $\mathrm{Na}^{+}$and $\mathrm{Ca}^{2+}$ due to calcite and feldspar dissolution. 

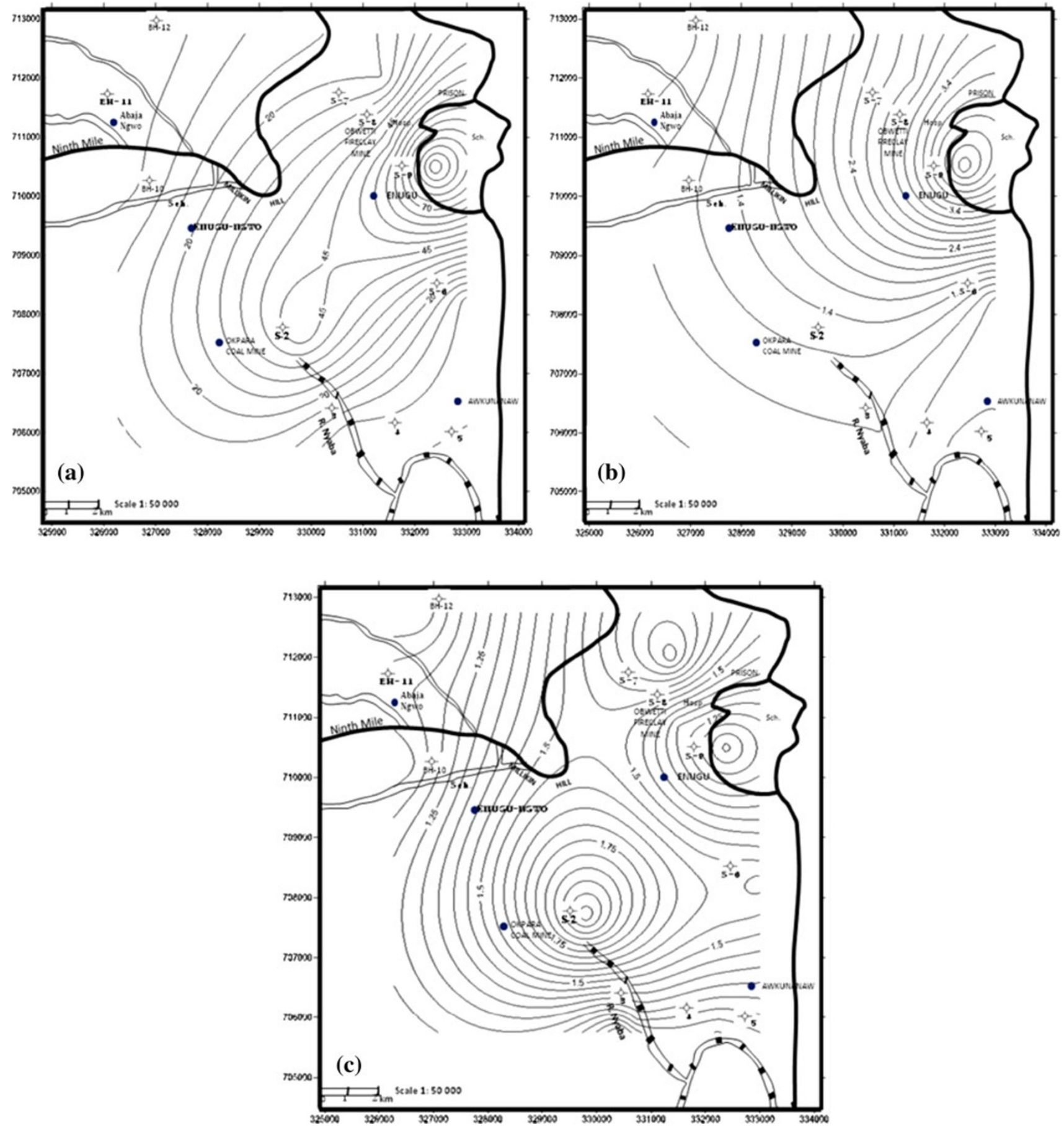

Fig. 8 Contour maps of the hydrochemical coefficients $\mathrm{SO}_{4} / \mathrm{Cl}(\mathbf{a}), \mathrm{Na} / \mathrm{Cl}(\mathbf{b}), \mathrm{Ca} / \mathrm{Mg}(\mathbf{c})$

On encountering the shale unit (containing some clay minerals), it is to be expected that $\mathrm{Na}^{+}$would be exchanged for $\mathrm{Ca}^{2+}$ according to the generalized reaction equation:

$2 \mathrm{NaAlSi}{ }_{3} \mathrm{O}+\mathrm{Ca}^{2+} \rightleftharpoons \mathrm{CaAlSi}_{3} \mathrm{O}+2 \mathrm{Na}^{+}$

Reaction in Eq. (6) thus results in a slight increase in $\mathrm{Na}^{+}$concentration and a decrease in $\mathrm{Ca}^{2+}$. This trend is qualitatively consistent with the measured concentrations.
Considering chloride ions to be a conservative chemical specie, simple assumption on the sea water origin of the analyzed water samples can be assessed by viewing the concentration ratios of chloride to other ions (Table 5). The ratio of $\mathrm{Na} / \mathrm{Cl}$ indicate a slight shortage of $\mathrm{Na}$ compared to that of seawater for samples S-2, S-3, S-4, S-5, S-6, S-11, and S-12. It was also found that while ratios of $\mathrm{Na}$ to $\mathrm{Cl}$ and $\mathrm{SO}_{4}$ to $\mathrm{Cl}$ generally increased, the ratios of $\mathrm{Ca}$ 
to $\mathrm{Mg}$ decreased. This kind of deviation has been attributed to ion adsorption/exchange processes due to the dissolution of drainage materials (Vuai 2001; Vuai et al. 2003). Generally, the ratio of $\mathrm{SO}_{4}$ to $\mathrm{Cl}$ in the analyzed water samples deviates remarkably from those of the river and seawater. These observations also provide characteristic signature of the well-water sample being possibly contaminated or unaffected by acid mine drainage and possible acidic lateritic soil, forestry activity, acid precipitation, and fulvic and humic soils.

These hydrochemical coefficients as shown in Table 5 have been noted to have great importance in the field of groundwater chemistry and have been used to determine the flow direction and the process of controlling the chemical composition of ground water (Fig. 8). According to Lloyd and Heathcote (1985), the chloride concentration normally increases down the hydraulic gradient and in the flow direction. In this study, the $\mathrm{Na} / \mathrm{Cl}$ ratio decreases toward the southeast. Hence, it can be considered that the flow direction is toward the southeast (Fig. 8b). The calculated ratio of $\mathrm{SO}_{4} / \mathrm{Cl}$ also shows a decrease toward the southeast (Fig. 8a), supporting a southeasterly flow direction of the groundwater in the area. This has also been noted by other investigators such as Nwankwor et al. (1988) and Egboka (1985) on the hydrogeology and geomorphology of the area. It was also noted that the $\mathrm{Ca} / \mathrm{Mg}$ ratio increase toward the direction of groundwater flow with Ca being more abundant than Mg (Fig. 8c; Table 6).

Table 6 Ratios of concentrations $(\mathrm{mg} / \mathrm{L})$ of dissolved species in the analyzed water samples

\begin{tabular}{llll}
\hline & \multicolumn{2}{l}{$\begin{array}{l}\text { Hydrochemical } \\
\text { coefficients }\end{array}$} \\
\cline { 2 - 3 } & $\mathrm{Na}^{+} / \mathrm{Cl}^{-}$ & $\mathrm{SO}_{4}{ }^{2-} / \mathrm{Cl}^{-}$ & $\mathrm{Ca}^{2+} / \mathrm{Mg}^{2+}$ \\
\hline $\mathrm{CS}-1$ & 1.28 & 100 & 0.79 \\
S-2 & 1.00 & 50 & 2.04 \\
S-3 & 0.75 & 1.82 & 1.27 \\
S-4 & 0.56 & 0.33 & 1.15 \\
S-5 & 0.93 & 3.03 & 1.00 \\
S-6 & 0.74 & 3.13 & 1.62 \\
S-7 & 2.78 & 20 & 1.83 \\
S-8 & 3.45 & 50 & 1.30 \\
S-9 & 4.76 & 100 & 1.08 \\
S-10 & 1.09 & 3.23 & 1.07 \\
S-11 & 0.81 & 1.39 & 1.15 \\
S-12 & 0.63 & 0.98 & 1.00 \\
Average value of Sea water & 0.90 & 0.1 & 0.2 \\
Average value of River water & 1.80 & 1.6 & 3.7 \\
Range values of study area & $0.56-4.76$ & $0.33-100$ & $0.79-1.83$ \\
Average value of study area & 1.57 & 27.83 & 1.27 \\
\hline The a & &
\end{tabular}

The average values of sea and river water from Al-Ruwaih and BenEssa (2004)

\section{Conclusions}

With respect to geologic and environmental consideration at the studied site, the shallow groundwater quality samples from water wells in the vicinity of Okpara coal and Obwetti fireclay mines, Enugu, Nigeria seem to pose no threat to human consumption. Except for sample for CS-1, the specific conductance of water, $\mathrm{pH}$, total hardness, as well as cations $(\mathrm{Ca}, \mathrm{Mg}, \mathrm{Na}, \mathrm{K})$ and anions $\left(\mathrm{NO}_{3}, \mathrm{Cl}, \mathrm{HCO}_{3}\right)$ are well below the WHO drinking water standards. Some of the waters, however, are characterized by concentrations of $\mathrm{Fe}, \mathrm{Mn}$ and $\mathrm{SO}_{4}$ higher than those of the WHO standard. This study, however, highlights that the past mining activities could be contributing to the quality of shallow well-water chemistry in the area around Okpara coal and Obwetti fire clay mines, Enugu (Nigeria). Aeration and filtration have been noted as the general treatment practice to reduce significant amount of Fe and Mn content. Treated waters are, therefore, suitable for drinking and domestic purposes. As noted before, lithological variations due to geology and environment of deposition form the best explanation for the local variation of each hydrogeochemical constituents. The aquiferous units mainly in the northwestern region of the study area yield water of better quality than those toward the southeastern region.

Acknowledgments The authors are grateful to two anonymous reviewers and Dr. A.U. Okoro for valuable and constructive comments. Financial support for this project was provided from the AAPG/Alexander and Geraldine Wanek Grant-in-Aid. Undergraduate student assistants in various field and analytical works: Maryjane U. Ezeike and Nnaemeka Okoli are also highly appreciated.

Open Access This article is distributed under the terms of the Creative Commons Attribution License which permits any use, distribution, and reproduction in any medium, provided the original author(s) and the source are credited.

\section{References}

Adaikpoh EO, Nwajei GE, Ogala JE (2005) Heavy metal concentration in coal and sediments from River Ekulu in Enugu, coal city of Nigeria. J Appl Sci Environ Manag 9:5-8

Akande S, Hoffkneht A, Erdtmann BD (1992) Rank and petrographic composition of selected upper cretaceous and tertiary coals of southern Nigeria. Int J Coal Geol 20:209-223

Al-Ruwaih FM, Ben-Essa SA (2004) Hydrogeological and hydrogeochemical study of the Al-Shagaya Field-F, Kuwait. Bull Eng Geol Env 63:57-70

Amadi PA, Ofoegbu CO, Morrison T (1987) Hydrochemical assessment of groundwater quality in parts of Niger Delta, Nigeria. Environ Geol Water Sci 14:195-202

American Public Health Association APHA (1995) Standard methods for the examination of water and waste water. American Water Works Association, Water Environment Federation, Washington Awoniyi JF (1977) Nigerian mineral industry: its history, trend and prospects. J Min Geol 14:73-78 
Barcelona M, Gibb JP, Helfrich JA, Garske EE (1985) Practical guide for groundwater sampling. Champaign: Illinois State Water Survey ISWS Contract Report 374

Callaghan T, Earle J (1998) Impacts of mine drainage on aquatic life, water uses and man-made structures. In: Ridge T, Seil JM (eds), Coal mine drainage prediction and pollution prevention in Pennsylvania, pp 1-22)

Caruccio FT (1968) An evaluation of factors affecting acid mine drainage production and groundwater interactions in selected areas of Western Pennsylvania. In: Proceeding of the 2nd symposium on coal mine drainage research, Monroeville Pennsylvania, pp 107-151

Caruccio FT, Ferm JC, Hern J, Geidel G, Buganz B (1977) Paleoenvironment of coal and its relation to relation to drainage quality. US Environmental Protection Agency Report No. EPA600, 7-067, pp 108

Celesceri L, Greenberg AE, Eaten AD (1998) Standard methods for the examination of water and waste water. American Public Health Association, Washington, p 134

Classen HC (1982) Guidelines and techniques for obtaining water samples that accurately represents the quality of an aquifer. Lakewood: US Geological Survey open file report 82-1024, pp 49

Daghrah GA (2009) Water quality study of Wadi Al Qilt, West Bank Palestine. Asian J Earth Sci 2:28-38

Davis SN, DeWiest RJH (1966) Hydrogeology. John Wiley and Sons, New York, p 463

Deutsch W (1997) Groundwater geochemistry: fundamentals and applications to contamination. Lewis Publishers, Boca raton, pp 232

Diala HN (1984) A review of some of the future problems and possible solution facing the Nigerian coal industry. Paper presented at the 20th Annual Conference of the Nigerian Mining and Geosciences Society. Nsukka, Enugu: University of Nigeria, Nsukka

Domenico PA, Schwartz FW (1990) Physical and chemical hydrogeology. Wiley Press, New York, pp 324

Egboka BCE (1985) Water resources problems in the Enugu area. In: Proceedings of the literature symposium on scientific basis of water resources management, Jerusalem, pp 95-106

Ezeigbo HI, Ezeanyim BN (1993) Environmental pollution from coal mining activities in the Enugu area, Anambra state, Nigeria. Mine Water Environ 12:53-62

Ghanem M, Ghannam M (2010) Spring water hydrogeochemistry along the north-south profile in the Jordan Valley. Asian J Earth Sci 3:122-129

Gleeson T, Wada Y, Bierkens MFP, van Beek LPH (2012) Water balance of global aquifers revealed by groundwater foot print. Nature 488:197-200

Gray NF (1996) Environmental impacts and remediation of acid mine drainage: a management problem. Environ Geol 30:62-67

Hackbarth D (2010) The effects of surface mining of coal on water chemistry near Grande Cache, Alberta. Alberta Research Council Bulletin 40

Hem JD (1985) Study and interpretation of the chemical characteristics of natural water. US Washington DC: geological survey water supply paper 2254 , pp 263

Hounslow AW (1995) Water-quality data analysis and interpretation. Lewis Publisher, New York, p 397

King A (1994) Application of geophysical method for monitoring acid mine drainage: MEND Project \#4.6.1. CANMET Library, 562 Booth St. Ottawa, Ontario, Canada

Lloyd JW, Heathcote JA (1985) Natural inorganic Hydrogeochemistry in relation to groundwater: an introduction. Clarendon Press, Oxford, p 296
Nganje TN, Adamu CI, Ntekim EEU, Ugbaja AN, Neji P, Nfor EN (2010) Influence of mine drainage on water quality along River Nyaba in Enugu southeastern Nigeria. African J Environ Sci Tech 4:132-144

Nganje TN, Adamu CI, Ugbaja AN, Ebieme E, Sikakwe GU (2011) Environmental contamination of trace elements in the vicinity of Okpara coal mine, Enugu, Southeastern Nigeria. Arab J Geosci 4:199-205

Nwankwor GI, Egboka BC, Orajaka IP (1988) Groundwater occurrence and flow pattern in the Enugu coal-mine area, Anambra state, Nigeria. Hydrol Sci J 33:465-482

Odoh BI, Utom AU, Egboka BCE, Okeke HC (2012) Geoelectric sounding for predicting shallow aquifer properties using modified Archie equations. Paper presented at the SEG-AGU hydrogeophysics workshop, Boise State University, Idaho, July 8-11

Ofili EI (2007) Nigerian standard for drinking water quality (NIS 554:2007). Standard Organisation of Nigeria, Abuja, Nigeria, p 30

Okagbue CO, Onuoha VO (1986) Environmental problems related to coal mining in Enugu area. In: Proceedings of the Nigerian Water and Sanitation Symposium on Groundwater Resources in Nigeria Ikeja, Nigeria, pp 23-24

Olowokudejo TA (2007) Targeting of high quality groundwater in the province of Vientiane, Laos, PDR. M.Sc Thesis, Lulea University of Technology, Sweden, pp 55

Piper AM (1953) A graphic procedure in the geochemical interpretation of water analysis. Washington. Geological Survey

Raghunath R, Sreedhara Murthy TR, Raghavan BR (2001) Spatial distribution of $\mathrm{pH}, \mathrm{EC}$ and total dissolved solids of Nethravathi river basin, Karnataka, India. Poll Res 20:413-418

Rai VK (2004) Suitability of surface and groundwater for irrigation: a case study. National Geographical Journal, India. VHU (up) 50:83-94

Reyment RA (1965) Aspects of the geology of Nigeria. Ibadan University Press, Ibadan, p 133

Reza R, Singh G (2009) Physico-chemical analysis of groundwater in Angul-Talcher region of Orissa, India. J Am Sci 5:53-58

Sanni LO (2007) Cassava post harvest needs assessment survey in Nigeria. IITA, pp 165

Simpson A (1954) The Nigerian coalfield - the geology of parts of Onitsha, Owerri and Benue Provinces. Geological Survey of Nigeria Bulletin 24, pp 67

Singh G (1987) Mine water quality deterioration due to acid mine drainage. Int J Mine Water 6:49-61

Singh G, Mridula B (1985) Bacterial formation of acid mine drainage, causes and control. J Sci Ind Res 44:478-485

Stumm W, Morgan JJ (1996) Aquatic chemistry. Wiley, New York, p 1022

Todd DK (1980) Groundwater hydrology. Wiley, New York, p 535

Uma KO (1992) Origin of acid mine drainage in Enugu. Environ Geol Water Sci 20:131-194

Utom AU (2012) Prediction of shallow aquifer parameters and water quality in Okpara coal mine and environs using geoelectric sounding. M.Sc Thesis, Nnamdi Azikiwe University, Nigeria, pp 106

Utom AU, Odoh BI, Okoro AU, Egboka NE (2012) An investigation into the use of electrical resistivity in aquifer contamination study: a case study. Near Surface Geoscience 2012, France-the 18th European meeting of environmental and engineering geophysics of the near surface geoscience division of EAGE, Paris, 3-5 Sept

Vuai SA (2001) Effects of red soils in chemical composition of natural water. M.Sc Thesis, University of the Ryukyu, Japan, pp 107

Vuai SA, Nakamura K, Tokuyama A (2003) Geochemical characteristics of runoff from acid sulfate soils in the northern area of Okinawa Island, Japan. Geochem J 37:579-592 